\title{
Nataliia Pohorila
}

\section{POLITICAL AND NATIONAL IDENTITY IN UKRAINE'S REGIONS: WHERE DOES THE CENTER FIT?}

DOI: $10.1515 /$ ppsr-2015-0033

\author{
Author \\ Nataliia Pohorila, PhD in Sociology, Department of sociology, Ukrainian Catholic University \\ pohorila@ucu.edu.ua
}

\begin{abstract}
This article is devoted to the issue of national identity and political preferences of the region of Central Ukraine. The essence of the "in-the-middle" position is tested using a national representative survey known as "Ukrainian Society" for the period of 2000-2012. This longitudinal survey allows for the delineation of tendencies of well-articulated political identities. This includes Galicia being compared to Crimea and Donbas. In this study these areas are compared to those of the Center, a region with an identity lacking thorough study. The specific trends in the development of a national identity and of political preferences are defined and compared within rural and urban populations in the analysed regions. The Center was chosen as a comparison to other Ukrainian regions as it characterizes the mobilization of political support in the formative years of Ukraine, commencing with the Orange Revolution in the fall of 2004.
\end{abstract}

Key words: state-nation identity, political choice, civilization theory, modernization.

\begin{abstract}
Acknowledgement: I would like to express my gratitude to Trevor FitzSimons Erlacher, from the Department of History, UNC College of Arts and Sciences, USA, the Fulbright scholar in Lviv in 2014, and to William Risch from the Department of History of Georgia College, USA. Their proofreading was more than just editing; it helped make my paper's argument more comprehensible.
\end{abstract}

\section{Why the Center is different: history of statehood and modernization}

The national identity of Central Ukraine has received relatively less attention than the Western and the Eastern regions have. The Central region of Ukraine is typically interpreted as "an intermediate zone" between the pro-European, nationalistic West and the pro-Russian Eastern oblasts. The West is depicted as embracing pro-independence, nationalism (Peisakhin, 2012, Shulman, 2005, Kubicek, 2000), and pro-European views (Darden, 2010, Barrington and Faranda, 2009, Arel, 2006), being more open to market reforms (Khmelko and Wilson, 1998), and supporting centrist and rightist parties (Birch 2000, Hesli, Reisinger and Muller,1998). In comparison, Eastern and Southern Ukraine are identified as the Russia-oriented population. This involves the values of work being highly hierarchized with a command economy typical for traditional heavy industry.

However, the «East-West Schema" overlooks Central Ukraine, which has a richer and longer history of autonomy than the Western and the Eastern parts of Ukraine. This paper argues that the Center has a distinct identity which translates into its political choices today - an identity which is deeply rooted in history. 
In Central Ukraine, since the fall of Kievan Rus', the successor territories passed from hand to hand. In the $16^{\text {th }}$ century, it became a part of the Polish-Lithuanian Commonwealth (formerly the Grand Duchy of Lithuania). However, in the $16^{\text {th }}$ century, the period of foreign rule in Ukraine was interrupted and groups of paramilitary Cossacks established their own state. The Cossack State was a unique attempt to create a state administration under the leadership of the local military elite-the Cossacks. It was the only attempt to create a sovereign Ukrainian state on the territory of Ukraine prior to 1917. Whatever the limitations of the "statehood" of the Cossack state, one can hardly deny that 150 years of political autonomy gave Ukrainians the sense of national self-awareness, an experience of political self-organization, and an idea of democratic rule.

After the abolishment of the Cossack rule in the $17^{\text {th }}$ century, the area became a Russian protectorate. Modernization of the Cossack lands, which included most of the Center and partially south of modern Ukraine, occurred under the aegis of St Petersburg and Moscow. It first spread to the Cossack lands and later to a scarcely-occupied Wild Steppe-Southern Ukraine, which later became known as the state project Novorossia. "Urbanization, industrialization, and transportation went hand in hand, as did education, communication, and social and ethnic differentiation" (Motyl and Krawchenko 1997, p.239). Since the end of the $19^{\text {th }}$ century, the modernization of Ukraine acquired the features of an industrial revolution with its culmination seen in the political project of the USSR, which was a "superior form of modernity, the corresponding attainment of high international status, a broad conception of social welfare, and a sense of social justice that was built into property relations" (Kotkin, 1995, p.358).

In western Ukrainian lands, which were under the protectorate of the Austro-Hungarian Empire, the modernization of the Ukrainian peasantry was held back by the Polish gentry. Still, thanks to Austro-Hungarian liberal reforms, Ukrainians achieved the right to represent their political interests in the Austro-Hungarian Parliament, started to organize their economic activity in cooperative and credit unions, and developed the institutions of informal education in addition to formal Ukrainian schools and university departments (Magosci 1996, Mokłak 2006). Thus, the modernization of Western Ukraine was cultural in its essence. On the other hand, weak industrial development led to slow changes in social structure; half of the region's population was still rural in the 1980s (Krawchenko 1985).

As a result of the $19^{\text {th }}$ and $20^{\text {th }}$ centuries' development in terms of modernization, the whole of Central Ukraine occupied an "in-the-middle" position between the west and southeastern regions. Heavy industry was far weaker than in the East. The increase in population was very slow until the 1960s when industrialization prompted the rural population to move to cities (Krawchenko, 1985). All types of industries and the service economy flourished only in Kiev, while other parts of the Central Region remained predominantly agricultural. Most of the cities of Central and, especially, Northern Ukraine, with the exception of Kiev, are small that the industrial megalopolises of the East. These smaller cities are much older than their Eastern counterparts, none of which are older than 200 years. One should expect that the Cossack legacy should have had a stronger influence on national identity here. On the other hand, since the late $18^{\text {th }}$ century, the cultural center for this region was located in St Petersburg, and later in Moscow, which caused the quick adoption to Russian language and culture.

There are two essential inner breaks across the regions in Ukraine: between the urban and rural population, and the West-East break, which is sometimes called the Great Steppe 
Frontier (McNeill 1964) or civilizational frontline (Dashkevych 1991). These breaks are important for understanding the identity of the Center. The tempo of modernization was much faster in the cities than in the rural areas that it might have caused the preservation of more archaic forms of national identity in villages than in the cities. As the experience of modernity was different in the West and the East of Ukraine, the consequences of a modernization gap could be different in these polar regions as well as in the Center.

The second inner break is the West-East break. It has been already mentioned that the history of the Center is marked by a 150-year long Cossack autonomy. However, the history of the Cossack lands was different, which, in turn, has its consequences for Cossacks. The northern part of the Center - the Zhytomyr, Chernyhiv, Kiev, and Sumy oblasts, and partially the Cherkasy oblast -are the earliest populated territories that were known in the $9^{\text {th }}-11^{\text {th }}$ centuries as a part of Kievan Rus. They are defined as belonging to the European civilization. In other words, this region is situated on the European part of the Great Frontier - the definition which the historian William McNeill gave to the border between Europe and Asia, between the Christian and Muslim worlds, and between the settled grain-growers and the nomads (McNeill, 1964, Dashkevych, 1991). Together with the Western Region, Northern Ukraine comprises the country's oldest civilized land, where the autonomous rule of the Rus' dukes existed until their subjugation by the Polish kings.

The middle part of the Central Region (Khmelnytsky, Kirovohrad, Poltava, Vinnytsia, and Southern Cherkassy oblast) is located beyond the Great Frontier. This region is either classified as a Wild Steppe or as a 'buffer zone' (Yakovenko, 2009), a sparsely populated land which, in the $15^{\text {th }}$ and $16^{\text {th }}$ centuries, bordered Rus' Lands from the territory of the Crimean Tatar Khanate and from the Turkish and, later, the Ottoman Empire ${ }^{1}$. The Cossack lands were divided into a "civilized" part where the Registered Cossacks (an analog of the Polish Gentry Register) founded the Hetmanate, a proto-independent state, and the Cossack Sich, a self-ruled and more "barbarian" part that existed independently of the ruling Hetman, whom they opposed (Lypynski, 1926). The Kirovohrad, Dnipropetrovsk, and Mykolaiv oblasts belonged to the buffer zone, and this included the north of the Kherson and the west of the Donetsk oblasts. These lands remained sparsely populated until the expansion of Russia in the $18^{\text {th }}$ century.

The question is whether the modernization and civilizational hypothesis can explain the political choices of the Center better than its "intermediate" position. In other words, does the internal split - urban/rural or Northern/Middle Central-help to explain the political orientation of the Center?

\section{When the Center differs: political choices}

In this section, I deal with the question of how the intermediate location of Central Ukraine translates into its political preferences. What does the "intermediate position of Central

${ }^{1}$ The areas of Dnipropetrovsk, Kherson, Mykolaiv, and, in part, Odesa and Zaporizhzhia oblasts are also defined by N. Yakovenko as the buffer belt, but in this study we do not study them as a part of the "Center". There were too many factors here preventing their classification as "the Center": demographic structure, geographic location and industrial profile. Applying geographic and economic approaches, Kherson, Mykolaiv, and Odesa are classified as the South, Dnipropetrovsk and Zaporizhzhia as "East” or "South-East" (Dnistrianskiy 2000, Shabliy 1995). It should be noted that the classification of these oblasts as "central", "southern" or "southern-eastern" has a consensual character and depends on the purpose of the analysis. 
Ukraine" mean? Whether the Center gets a view closer to the West or to the East depends on variables and studied the period of time. For example, the Center occupies a moderate position concerning Russia and the status of the Russian language, while at the same time the Center agrees with the Western Regions in matters of economic and political liberalization (Khmelko and Wilson, 1998). During the 1994, 2004 and 2010 presidential elections, when geopolitical orientation become an issue, the Center altogether allied with the West, voting against pro-Russian or Communist candidates (Bilychenko, 2010, Nichoga, 2010). However, the Center did not ally during the Kuchmagate crisis (2000-2001). Altogether, the interpretation of "the Center" assumes "volatility": a position of uncertainty in the situation of choice, when the victory of a pro-Western or a pro-Russian candidate depends on how the Center votes.

The data on voting for the political opponents illustrates the shifts of the "intermediate position" of the Center relative to the opposite East-West poles. I used the second round voting results for the Communist Party of Ukraine in the three Parliamentary elections of 2002, 2006, and 2012; voting for the Party of Regions in 2006 and 2012; and voting for its main competitors, "Nasha Ukraina" and BYUT in 2002 and 2006 (Graph 1)2.

\section{Graph 1. Voting at the Parliamentary elections 2002-2012, percent by Central election committee (CEC)}

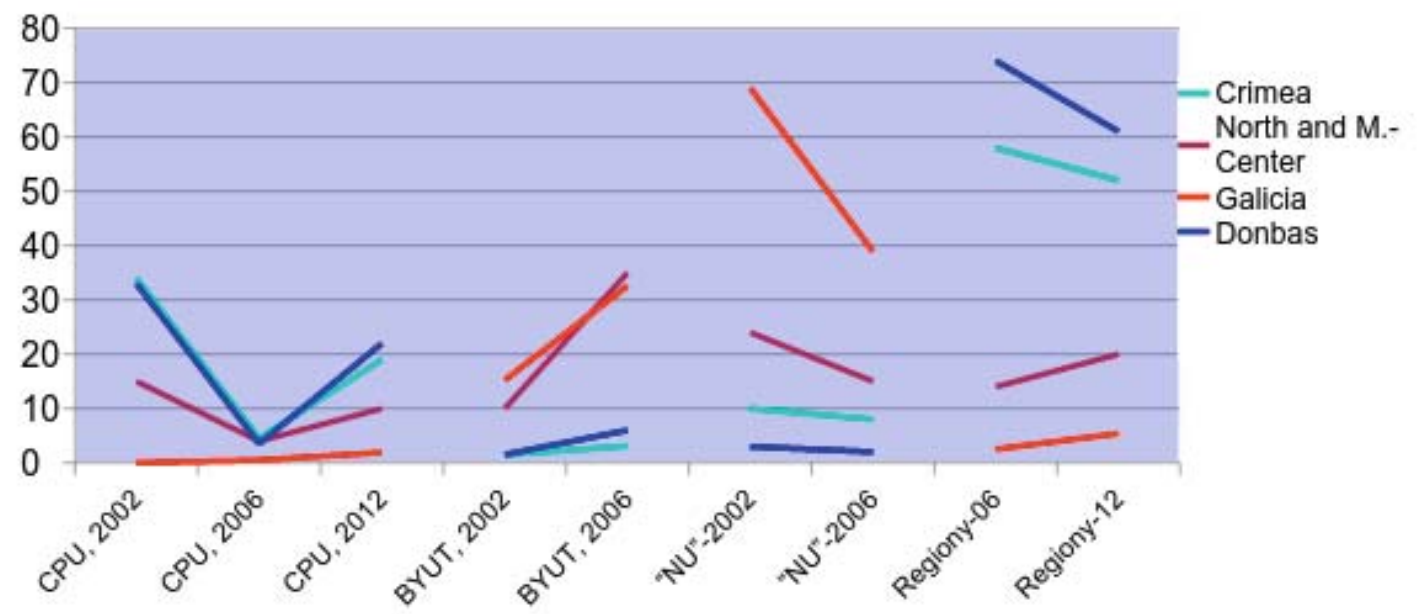

${ }^{2}$ In the present study, "Galicia” is composed of the Lviv, Ternopil, and Ivano-Frankivsk oblasts, which roughly represent the historical region of Galicia, with the highest adherence to Ukrainian language and opposition to Russia. Donbas is composed of the Donetsk and Luhansk oblasts. The Zhytomyr, Chernihiv, Kiev and Sumy oblasts are the Northern region; Khmelnyts'ky, Vinnitsa, Cherkassy, Poltava and Kirovohrad Oblasts are the Mid-Center. The remaining oblasts - five Western Northern oblasts - Volyn, Rivne, Chernivtsi and Zakarpattia; three eastern oblasts - Zaporizhzhia, Kharkiv, and Dnipropetrovsk; and southern oblasts - Kherson, Odesa, and Mykolaiv oblasts - are not considered in the graphs. They are not shown in the graphs with the exception of Graph 3. Demographics (the share of rural population), the share of the Ukrainian language in use, and economic structure (mixed industrial and agricultural) make these oblasts more difficult to be classified with the "west", "center", "south" or "east" (Dnistrianskiy 2000, Shabliy 1995). Crimea is considered separately from other southern oblasts as it differs from them by a larger share of ethnic Russians, the structure of the economy, and the later date of joining Ukraine. Graph 3 represents nicely why only these regions can be explicitly compared: including of all oblasts makes the picture blur. 
The North and the Mid-Center are counted together because voting results there hardly differed. CPU stands for the Communist Party of Ukraine. BYUT stands for the Bloc of Yulia Tymoshenko, the Prime Minister in 2005, who after the split of the Orange coalition in 2006 became the main competitor of the Party of Regions and embodied the role of a pro-Western political force. The NU stands for political Party "Nasha Ukraina", which in the first half of the 2000s became a representative of the interests of the Ukrainian-speaking population and the idea of European integration and, thus, the opponent of the Party of Regions. After the Parliamentary elections of 2006, NU lost its dominant status in the political arena to the Party of Regions. The Party of Regions is the party of Viktor Yanukovych, the Prime Minister of 2006-2009, and the President of Ukraine 2010-2014.

As can be seen, the Center, both the Northern and Middle-Central parts, is in between the polarized electorates of the West and Southeast in voting for the candidates in the Parliamentary elections, whether it is the Communist party, the NU, or the Party of Regions. However, it is the distance between the electorates that matters. The Center is on the somewhere in the middle between the opposing regions in the case of the CPU; its voting results are more like in the Southeast with respect to the low rating of NU, but more like Galicia in rejection of the main competitor of NU - the Party of Regions. It also resembles Galicia in voting for the "BYUT".

When observing the changes in voting, we can see that the Center is not aligned with the voting outcomes in Galicia or Donbas. In the period of the fall-and-rise of the CPU's popularity in the Center, the drop in the ratings was smaller than in the Donbas and Crimea. The Center was neither too enthusiastic when the CPU's popularity was regained. The Center did not show a dramatic decline in the support rates for the NU after the Orange Revolution. The disappointment of the Galicians was much deeper ${ }^{3}$. When certain disillusionment with the rule of the Party of Regions in Donbas and Crimea was observed after 2006, the support rating of this party winner only slightly grew in the Center. In the Center, regarding political opponents, the support for their favorite parties was high, but no party received more than 37 percent of the votes from Central Ukraine. It can be said that no party could clinch massive support in the Central region and, correspondingly, no party ever experienced steep losses there.

\section{The volatile position of the Center}

Thus, the electorate of both parts of Central Ukraine show less emotions in political choice, lacking either strong loyalty, or disappointment with political figures. Does this mean that the "volatility" of the Center is a stereotype? Could it be said that the victory of the two competing political programs depends on how the Center voted? Graph 1 shows exactly the opposite: the change of the preferences in the Center in 2002-2006 helped to consolidate the position of the BYUT, but there were no other influential changes observed. Is there anything specific about political mobilization in the Center?

\footnotetext{
${ }^{3}$ In the events of the autumn of 2004, a political coalition of the "NU" and BYUT united in their fight against corruption in politics and business, embodied in the popular imagination by Leonid Kuchma. The winning coalition, which obtained the name "Orange", received the presidential post for Viktor Yushchenko ("NU") who appointed Yulia Tymoshenko as the Prime Minister. The year of 2005 is known as the year of disappointment, when the policy of the Oranges was found to be inconsistent, vindictive, and controversial, the coalition of Orange politicians dissolved. The Orange politicians were practically defeated with the victory of their opponents, the Party of Regions, in the parliamentary elections of 2006.
} 
As Graph 2 depicts, the voters of Central Ukraine show an overwhelming ability to mobilize themselves in response to the radicalization of the political situation. From the first round to the third round, voting for Yushchenko increased sharply by 16 percent. The political situation on the eve of the presidential elections of 2004 was tenser than in any other election. Rumors of massive fraud signaled problems at the level of the nation's integrity, prompting a million protesters to rally. Under the aggravating tension, the Center turned radically westward. On Graph 2, one can see that the position the Center shifted closer to the standing of Galicia ${ }^{4}$.

The comparison of the voting reported in "Ukrainian Society" to the data from the Central Electoral Committee exhibits another important feature of political behavior in the Center. While in the self-reported votes given to Yushchenko are almost identical with official data Donbas and Galicia, in the Center, reportedly, there were more voicesvotes than the official rating provides. It seems that a bandwagon effect was significant throughout Central Ukraine.

\section{Graph 2. Voting for V.Yushchenko given in 2005 in "Ukrainian Society" versus data on voting by the Central Election Committee (CEC)}

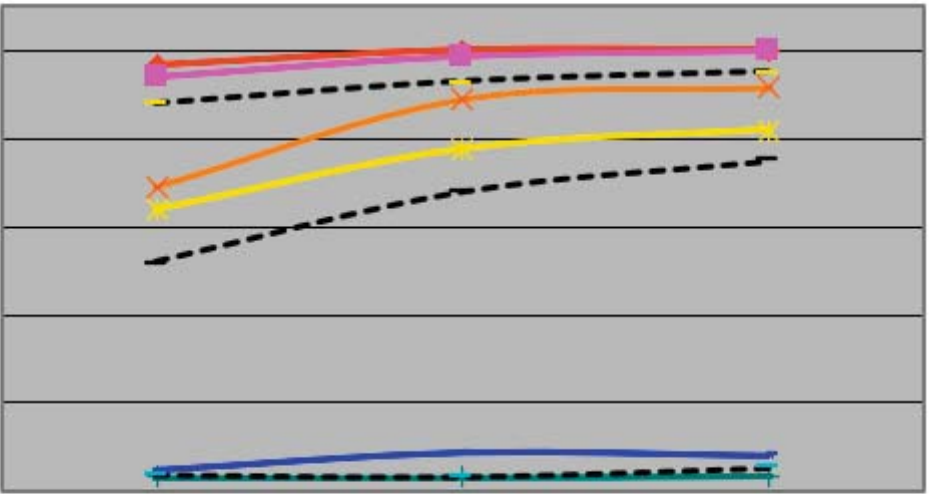

$\longrightarrow$ Galicia rural, survey

- Galicia urban, survey

-..-Galicia, CEC

$\longrightarrow$ North and M.-Center rural, survey

North and M.-Center urban, survey

- - North and M.-Center, CEC

- Donbas rural, survey

Donbas urban, survey

- - Donbas, CEC

Donbas and Crimea are shown together because of the results in these two regions hardly differed.

We can observe in Graph 2 that the rural areas of the Center differed from the urban units: rural dwellers mobilized faster. It could possibly signify a stronger role of emotions in political choices among the rural dwellers.

The regression equation in Table 1 depicts how much the "volatility" of political choice is distributed within the regions of Ukraine and the Ukrainian speaking population. I take as an indicator of volatility the changes in political preferences observed in 20042006. In 2006, the respondents were asked how they voted in the Presidential elections of

\footnotetext{
${ }^{4}$ The self-reported data on voting are taken from the annual survey "Ukrainian Society" conducted by the Institute of Sociology, National Academy of Ukraine, in March 2005 targeting the national representative sample of the adults in Ukraine $(\mathrm{N}=1800)$.
} 
2004, and in the Parliamentary elections of 2006. At the moment of this study in 2006, the electorate of Yushchenko was extremely disappointed, as the abysmal rating of his party, the NU, proves. As a result, the disappointed majority of the former NU- supporters split into two groups: those who voted for the BYUT, the party of Yulia Tymoshenko, the defeated part in the Orange coalition's conflict, and those who voted for the Orange coalition's opponents - the Party of Regions and the CPU. The former is defined as "moderately disappointed", while the latter as "radically disappointed". These two groups of non-loyal voters are considered as two different degrees of volatility, and they are considered as a dependent variable in the multinomial regression.

Table 1. Change of political preferences between Presidential elections in 2004 and Parliamentarian elections of 2006, "Ukrainian Society" survey, multinomial regression, exp (B).

\begin{tabular}{|c|c|c|c|c|c|c|c|c|c|}
\hline & \multicolumn{3}{|l|}{ Model I } & \multicolumn{3}{|l|}{ Model II } & \multicolumn{3}{|c|}{ Model III } \\
\hline & $\begin{array}{l}\text { Did not } \\
\text { vote for } \\
\text { Yushch } \\
\text { or NU } \\
\mathrm{N}=615\end{array}$ & $\begin{array}{l}\text { Radical- } \\
\text { ly disap- } \\
\text { pointed } \\
\mathrm{N}=195\end{array}$ & $\begin{array}{l}\text { Mod- } \\
\text { erately } \\
\text { disap- } \\
\text { point- } \\
\text { ed } \\
\mathrm{N}=276\end{array}$ & $\begin{array}{l}\text { Did not } \\
\text { vote for } \\
\text { Yushch } \\
\text { or NU } \\
\mathrm{N}=615\end{array}$ & $\begin{array}{l}\text { From } \\
\text { Yushch } \\
\text { to } \\
\text { other } \\
\text { parties } \\
\mathrm{N}=195\end{array}$ & $\begin{array}{l}\text { From } \\
\text { Yushch } \\
\text { to } \\
\text { BYUT } \\
\mathrm{N}=276\end{array}$ & $\begin{array}{l}\text { Did not } \\
\text { vote for } \\
\text { Yushch } \\
\text { or NU } \\
\mathrm{N}=615\end{array}$ & $\begin{array}{l}\text { From } \\
\text { Yushch } \\
\text { to } \\
\text { other } \\
\text { parties } \\
\mathrm{N}=195\end{array}$ & $\begin{array}{l}\text { From } \\
\text { Yushch } \\
\text { to } \\
\text { BYUT } \\
\mathrm{N}=276\end{array}$ \\
\hline Galicia & 0,01 & 0,64 & 0,88 & 0,01 & 0,74 & 0,87 & 0,02 & 0,50 & 0,40 \\
\hline Center & 0,32 & 1,36 & 2,45 & 0,40 & 1,50 & 2,44 & 0,25 & 0,81 & 1,21 \\
\hline $\begin{array}{l}\text { Crimea and } \\
\text { Donbas }\end{array}$ & 50,48 & 3,29 & 1,28 & 29,99 & 2,49 & 1,30 & 28,40 & 2,31 & 1,18 \\
\hline Rural & 0,32 & 0,63 & 0,51 & 0,43 & 0,70 & 0,51 & 0,26 & 0,36 & 0,16 \\
\hline $\begin{array}{l}\text { Native } \\
\text { language } \\
\text { Ukrainian }\end{array}$ & & & & 0,22 & 0,46 & 1,00 & 0,23 & 0,47 & 1,07 \\
\hline $\begin{array}{l}\text { Rural x } \\
\text { Center }\end{array}$ & & & & & & & 2,53 & 3,50 & 5,21 \\
\hline $\begin{array}{l}\text { Rural x } \\
\text { Galicia }\end{array}$ & & & & & & & 0,00 & 2,01 & 5,74 \\
\hline $\begin{array}{l}\text { Cox and } \\
\text { Snell }\end{array}$ & \multicolumn{3}{|c|}{0,450} & \multicolumn{3}{|c|}{0,475} & \multicolumn{3}{|c|}{0,484} \\
\hline Nagelkerke & \multicolumn{3}{|c|}{0,488} & \multicolumn{3}{|c|}{0,515} & \multicolumn{3}{|c|}{0,524} \\
\hline
\end{tabular}

Reference group: "Voted for Yushchenko in 2004" and voted for the NU in 2006.

Bold font is for $\mathrm{p}<0.01$, italic for $0.05<\mathrm{p}<0.01$

The number of the 2004-Yanukovych electorate who voted in 2006 for the NU and BYUT, his opponents, is so small that they do not comprise any group for reliable inferences.

The result of the analysis shows that the voters of the Center are 2,5 times more often than the inhabitants of the other regions found among the moderately disappointed. The 
voters from Crimea and Donbas tend to change their preferences in more radical way, but the coefficient of 3,3 is not statistically significant.

Generally, rural inhabitants tend to more rarely be moderately disappointed than the urban inhabitants, which is marked by the coefficient 0.5 , making this statistically significant. However, Model III indicates that this is not the case of the rural habitants from the Central region. They changed from Yushchenko's party to that of his former ally, the BYUT, 5 times more often than other categories of citizens, and they changed from the Orange coalition's parties in favor of its opponents from the 2004 campaign 3,5 times more frequently. Thus, the volatility of the Center is ensured by its rural inhabitants: they tend to change their loyalty more frequently than rural dwellers of other regions. However, the tendency to be moderately disappointed was also observed among the rural inhabitants of Galicia; therefore, the volatility of rural voters is not exclusively a "Central phenomenon".

Model II illustrates the well-known fact that the NU electorate was Ukrainian speaking (the coefficient is 0,2 ). As for the voters from Crimea and Donbas, introducing the Ukrainian language in Model II reduced the odds of voting for non-Orange forces by almost two times. It can be concluded that it is not all inhabitants of Donbas and Crimea who voted for no Orange forces, but Russian speakers only. Command of Ukrainian as the native language reduces the chance to be found among the radically disappointed respondents by half. Therefore, adherence to the Ukrainian language guaranteed loyalty to the Orange politicians in 2004 and 2006.

\section{Changes to national identities in Ukraine's regions}

Political preferences in Ukraine are indispensably correlated with national identity as politicians in the 2000s took opposite stands toward the national sovereignty of Ukraine, Western versus Russian patterns of integration, and the status of the Russian language. The elections of 2004 revealed the interregional split that is often described as "civilizational". The West and the Center voted for Viktor Yushchenko and the political coalition of the "Oranges", who became the symbols of a fight for fairness and transparency in politics and business, national independence, and pro-Western development, while the East and South voted for Viktor Yanukovych, who embodied the values of a post-Soviet type of industrial development, clan-based economics, and a strong relationship with Russia. The events of the winter of 2013-2014 brought evidence of a deepening of the interregional split as the Center and West joined massive protests against the pro-Russian policies of Yanukovych.

The civilizational split, which is believed to have deep historical roots, has been reinforced by the clash of the two modernization models: the modernization of the Eastern-Southern part based on urbanization and industrialization and the modernization of the Western part based on a European type of social relationships at the levels of public policy, work and education. These two types of modernization could have given the impulse for the development of the different kinds of national identity: "state-nation" and "ethno-state". "State-nation" identity is constituted by a perception of citizenship as a defining feature of national identity, while "ethno-nation" is the identity based on memory about one's embeddedness in the nation's territory, its ethnicity, and culture (Haller and Ressler 2006, Kohn 1967, Smith 1991, Brubaker 1992). State-nation identity is specified as 
a modern identity, the basis for a political nation, while ethno-state as primordial, developed in stateless nations.

Which type of identity prevails in Ukraine? The theory of modernization propels us to expect that urban dwellers, who enjoyed the fruits of modernization of social structure and experienced mobility, would rather prefer the modern "state-nation" identity, while the Ukrainian peasantry would prefer the "ethno-state" national identity (Kasjanov 1999, Prysiazhniuk 2008). If state-nation identity is a modern phenomenon, then we would expect that it is more typical for urban populations. Since most of the large modern cities are concentrated in the southeastern part, then the "state-nation" identity will be more common there. On the other hand, Western Ukraine might have developed a state-nation identity due to its cultural modernization and pro-independence orientations. The fact that rural population is much higher in Western and Central Ukraine than in the Southern, and, especially, Eastern parts, makes the question even more complicated.

The "Ukrainian Society" survey contains a question on "national identity": "How do you identify yourself?"5 The pre-coded answers included the following options: "Inhabitant of the village/city I live in"; "Inhabitant of the region I live in"; "Citizen of Ukraine"; "Representative of a nation, ethnos"; "Citizen of Europe"; or "Citizen of the world". The answer "Citizen of Ukraine" is taken as the indicator of state-nation identity.

Identification as a citizen of Ukraine was the most popular option selected by 35 to $60 \%$ of those interviewed in 2000-2016. Local identity ("Habitant of the village/city I live in") was second most popular with slightly more than one third of the responses. Regional identity ("Habitant of the region I live in") had 5-7\% and ethnic "Representative of a nation, ethnos" had 2-3\%. These three types of identities can be typified as "primordial" and considered as a main alternative to the state-nation identity, since they were based on the attachment to ethnicity, tradition, and geography without aspirations to belong to a larger entity-a nation. The option "Soviet citizen" is, in a way, a modern national identity. However, a perpetually decreasing number of respondents with the related identity proves that this is rather a phantom identity. The smallest number of respondents declared cosmopolitan identities at about $2 \%$.

Graph $3^{6}$ depicts a steady growth of the state-nation identity with the two choices: more noticeable in 2005, and less noticeable in 2014, in the aftermath of the two revolutions. This growth and two rapid increases were observed in all nine regions. The interregional differences were statistically significant, showing a persistently highest level of national identification in Galicia and the lowest in Crimea. The two lines that represent the Center-North and Middle Center-closely follow the lines for the other regions with the notable exception of Crimea. On average, for sixteen years, only in Galicia the identification with the Ukrainian state was stronger than in the Center in all the observation time points, and the East and Crimea were distinctly lower than the other oblasts.

\footnotetext{
${ }^{5}$ This question was asked in 2000, 2001, 2002, 2003, 2004, 2005, 2006, 2008, 2010, and 2012. The field stage has been carried out by the company SOCIS on January-February of each year during 2000-2004, and on March-April since 2005.

${ }^{6}$ Lviv, Ternopil, Ivano-Frankivsk Oblasts - Galicia; Volyn and Rivne Oblasts - the Northern West; Chernivtsi and Zakarpattia Regions - the Southern West; Zhytomyr, Chernihiv, Kiev and Sumy oblasts - Northern region; Khmel'nyts'ky, Vinnytsia, Cherkasy, Poltava and Kirovohrad oblasts - the Middle-Center; the Southern Oblasts - Odesa, Kherson and Mykolaiv; Dnipropetrovsk and Zaporizhzhia oblasts - the Southern East; Kharkiv, Donetsk and Luhansk oblasts - the East; Crimea.
} 


\section{Graph 3. State-nation identity in nine regions of Ukraine, percent}
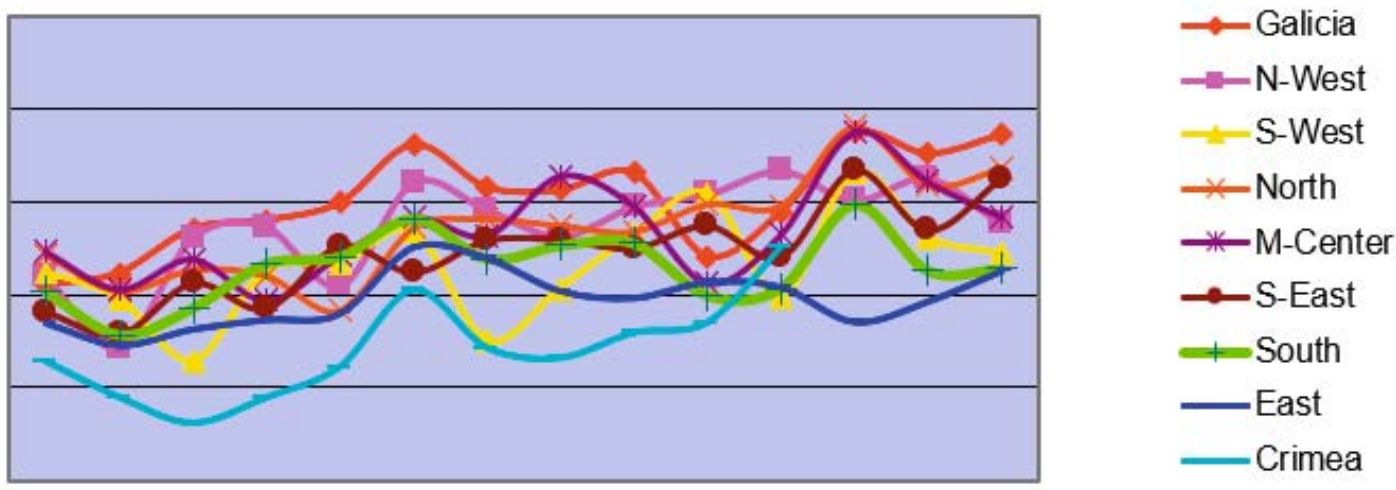

The dynamics of all regions, besides Galicia, the Eastern region, and Crimea, are not easy to follow in Graph 3, as it is affected by too many trends. Graph 4 presents two parts of the Center, Northern, and Middle-Center, contrary to those three polar regions. Graph 4 reveals the data only on the aftermath of the four Presidential elections of 1999, 2004, 2010, and 2014. Three of the depicted years are also the aftermath of mass protests in 2000,2005 , and 2014. It can be seen that the only region showing an ascending uninterrupted growth of the state-nation identity is Northern Ukraine. The state-nation identity of the inhabitants of Galicia and the Middle Center fell in reaction to the disappointment of 2005 and, at the same time, it had not changed in Donbas and Crimea. The events of 2013-2014 caused an increase in state-nation identity and made the detachment of the East sharp again.

\section{Graph 4. State-nation identity in Galicia, Crimea, Donbas and two central regions, North and Middle-Center, percent}
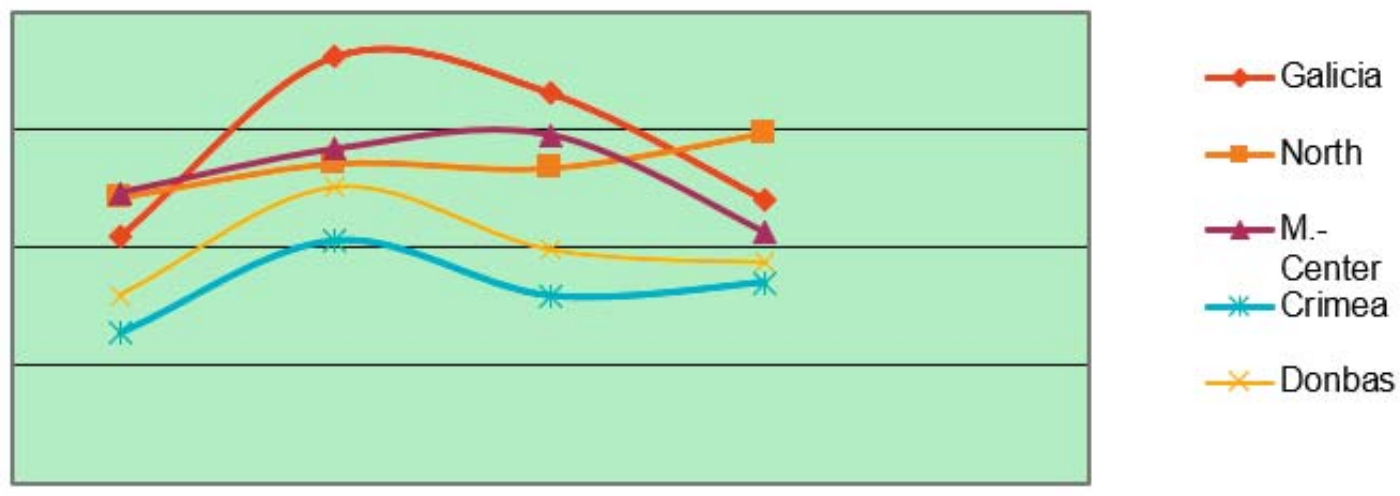

The Center shows a prominent urban-rural split, especially in the post-revolution year of 2005 and after the defeat of the Oranges in 2010 (Graph 5). It is not just the fact that the Center urban dwellers have a stronger state-nation identity, but the trends are divergent from each other. While we see a growth of state-nation identity in urban units of the Northern and the Middle-Center in 2000-2005, the rural areas remained still. When the 
urban population of the Middle-Center and the rural population of both central regions showed some drop in national identity after 2010, the urban dwellers of the North were strengthening their state-nation identity. Though the trends converged in 2014, the data of 2005 and 2012 demonstrated that the rural/urban gap could be no smaller than the interregional gap.

\section{Graph 5. State-nation identity in the northern and central oblasts, percent}
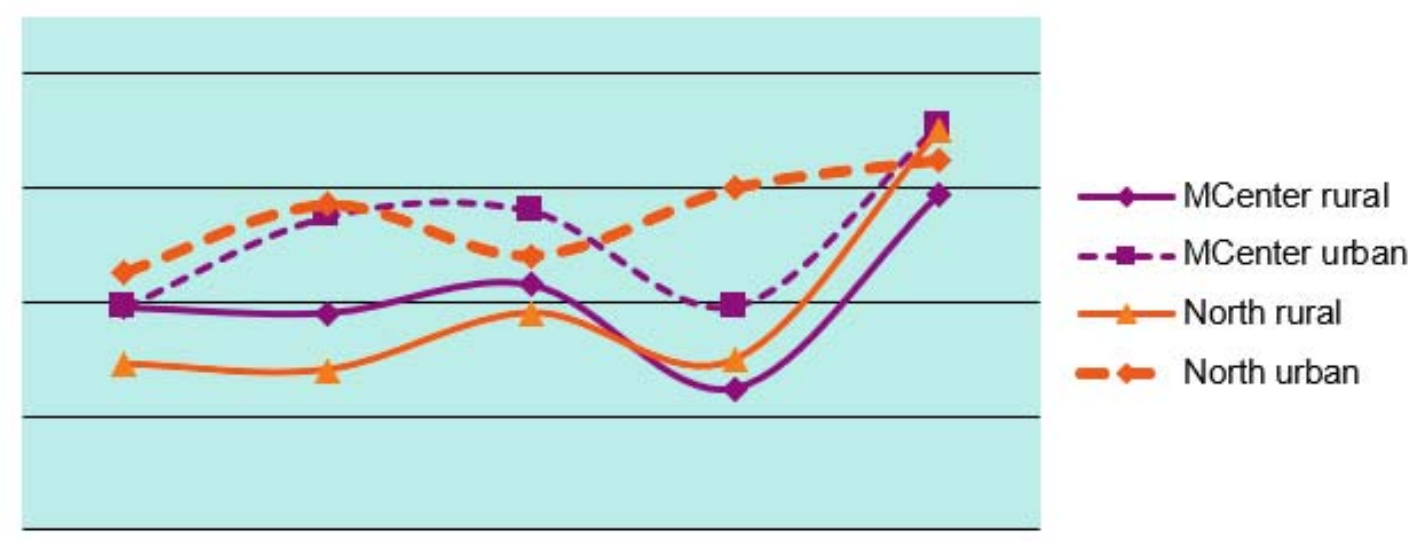

In Galicia, the East and Crimea, no "urban-rural" differences were detected until 2012 (Graph 6). From 2010-2012, a prominent drop of the state-nation identity was observed in rural areas of both Galician and Eastern regions. Identification with the Ukrainian state remained stable in urban areas, though. After the Maidan and the Revolution of Dignity, the state-nation identity had increased abruptly, but not in the Eastern and Crimean cities.

Graph 6. State-Nation Identity in Galicia and Crimea/Donbas, percent
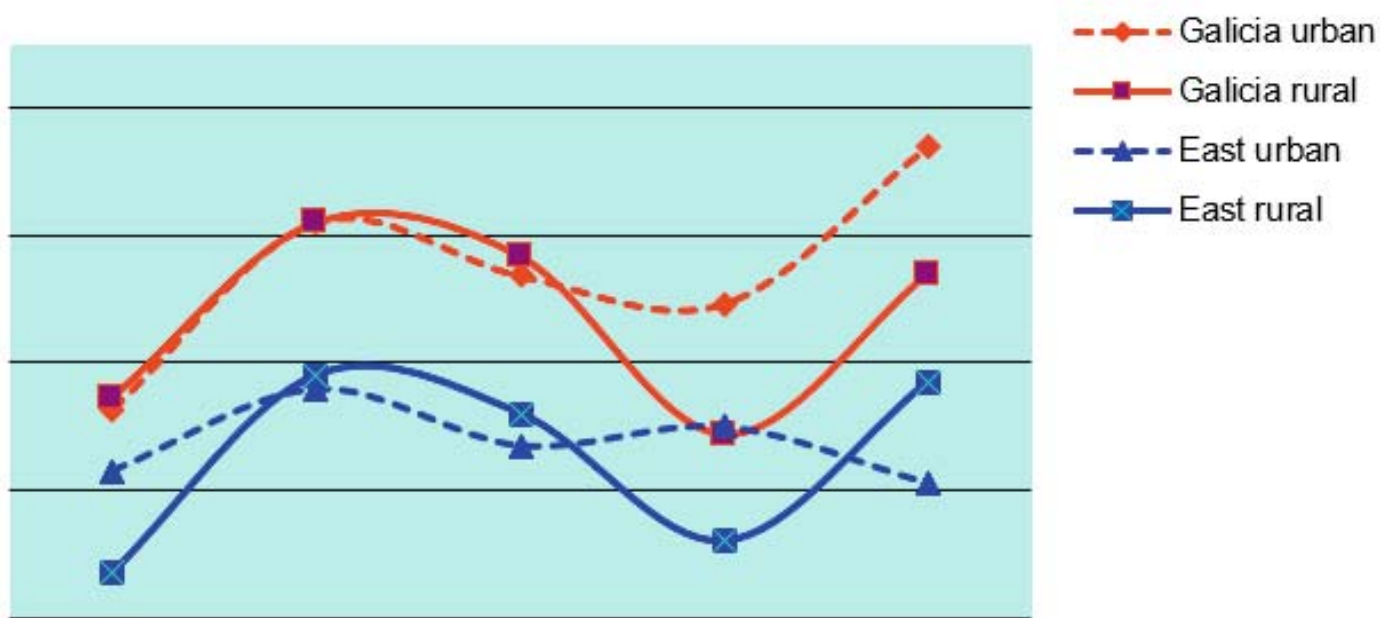

Crimea and Donbas are merged here with other Eastern oblasts in order to get enough observations in rural areas.

The question is whether the variation in state-nation in the Ukrainian regions and within urban and rural population can be translated into political preferences and where the Center will be found on the political scale. 


\section{National identity and political choice}

The remaining question is whether and to what extent political choices are circumvented by national identity, or do each of these two variables develop independently by their own logic. High ratings for a presidential candidate means that he/she embodies some idea that integrates a significant part of a society. If the state-nation identity correlates with voting for Yushchenko, it means that he embodies the national idea of citizenship as a cornerstone of nation-building. However, if he is supported by those with local or regional identity, he embodies strong localism, adherence to tradition, to the Ukrainian language in the Western and Central oblasts, and to a parochial political identity. The problem is that Yushchenko was supported massively by the rural and Ukrainian-speaking population of the Center and West, while, according to the "Ukrainian Society" data, state-nation identity was two times less popular among rural dwellers, who are more numerous in Western and Central oblasts, as is the Ukrainian speaking population.

The analysis of voting for Yushchenko in 2004 shows that the respondents with state-nation identity voted for him twice and the rural voters 3 times more often than the other voters (Table 2). The fact of living in the Center increased the probability that the voter supports Yushchenko by almost 4 times. The most powerful predictor of the voting for Yushchenko was Ukrainian language use. The introduction of the Ukrainian language in the equation reduced the coefficients for the rural and Central regions' population almost by half. Thus, the support for Yushchenko had been localized in the Western oblasts - up to $100 \%$ of votes in Galicia - and among Ukrainian speaking and rural populations of Central Ukraine. What is the role of state-nation identity in voting for Yushchenko? Does this role differ in the regions of Ukraine? Could it be that the urban-rural gap in the development of state-nation identity affects the political choice?

The interaction term of state-nation identity with the Central region produced a significant coefficient with a value much smaller than " 1 ". This means that despite voters with state-nation identity and those who live in the Central oblasts supported Yushchenko more, those with a stronger state-nation identity living in the Center supported Yushchenko less than the other categories. Thus, although the definition of Yushchenko as a state-nation model works throughout Ukrainian society, it does not work in the Central oblasts, where voting for him does not necessarily mean adherence to a state-nation identity. The same result was obtained for the Ukrainian language in use. Though Ukrainian speakers tend to vote for Yushchenko more often than Russian speakers, in Central Ukraine the Ukrainian speakers tend to vote less compared to Ukrainian speakers in other regions. This result must not be misinterpreted. As everywhere else, in Central Ukraine there are more of Yushchenko's electorate among Ukrainian speakers and those with a state-nation identity. However, the Ukrainian language and a state-nation identity play a less important role for political choice in Central Ukraine than in all other regions. It can be argued that neither of the two models - state-nation or ethno-nation-can be applied to the political identity of the Center. It was possible that Yushchenko embodied a model of integration, some inclusive model of statehood that appeals to Russian speaking Ukrainians who comprise one-third of the population of the Center. On the other hand, many of the Russian speakers, supporters of Yushchenko, prefer local identity to state-nation, which means that a state-nation explanation does not fit here. 
Table 2. Voting for Yushchenko in 2004 and the place of residence, "Ukrainian Society" survey $2005(\mathrm{~N}=1466)$, logistic regressions, $\exp (\mathrm{B})$.

\begin{tabular}{|l|c|c|c|}
\hline & Model I (N=1466) & Model II & Model III \\
\hline Constant & $\mathbf{0 , 4 2}$ & $\mathbf{0 , 2 1}$ & $\mathbf{0 , 1 5}$ \\
\hline State-nation identity & $\mathbf{1 , 8 2}$ & $\mathbf{1 , 5 7}$ & $\mathbf{2 , 1 3}$ \\
\hline Rural & $\mathbf{2 , 7 9}$ & $\mathbf{1 , 6 5}$ & $\mathbf{1 , 5 9}$ \\
\hline Center & $\mathbf{3 , 9 3}$ & $\mathbf{2 , 5 2}$ & $\mathbf{1 0 , 4 9}$ \\
\hline Ukrainian language as native & - & $\mathbf{5 , 5 0}$ & $\mathbf{7 , 0 2}$ \\
\hline State-nation identity x Center & - & - & $\mathbf{0 , 3 5}$ \\
\hline Ukrainian language x Center & - & - & $\mathbf{0 , 3 4}$ \\
\hline Cox\&Snell & 0,146 & 0,238 & 0,252 \\
\hline Nagelkerke R & 0,196 & 0,319 & 0,337 \\
\hline
\end{tabular}

Bold font is for $\mathrm{p}<0.01$, italic for $0.05<\mathrm{p}<0.01$

\section{Conclusions}

This article provides an original framework to analyze the political and national identity of Central Ukraine, usually defined as an "in-the-middle" identity, between the West and East. The analysis brought some evidence that Central Ukraine has an identity of its own, circumvented by its history, complex and known by early attempts at state building.

Residents of the Center are not inclined to support radical political opponents, and they do not change their political allegiance too easily. Still, the electorate of the Center can be quickly involved in the political process in a situation when the geopolitical orientations of Ukraine are in question, as it was during the Orange Revolution. In the period of national upheavals like the Orange Revolution and the Revolution of Dignity, the population of Central Ukraine aligned with Western Ukraine.

Rural inhabitants of the Center are fast in mobilization if national security is in question, but they also tend to be disappointed easily. The same tendency is observed with the development of the state-nation identity. Identification with the Ukrainian state grew and fell in correspondence with the rise and fall of political forces which attracted the sympathy of the rural population. In contrast, the urban population of the Center, especially of its Northern part, show a more steady development of identification with the Ukrainian state, the state-nation identity. A longitudinal study of this urban-rural split should be done in order to understand whether it is the specificity of the Central region or maybe some other regions also show the same sort of split.

The most interesting finding is the particular model of correlation between national identity and voting preferences, which was observed among the respondents of the Central oblasts. While in Galicia and Eastern Ukraine state-nation identity and the language in use explain the choice or the presidential candidate in a predicable manner, in Central Ukraine it looks different. While wherever else in Ukraine voters with stronger state-nation identity voted more often for Yushchenko, in Central Ukraine they voted less for 
him. It is observed that, in Central Ukraine, Russian speaking people and people with local identity voted for Yushchenko more often than in other regions, where the same category would vote for Yanukovych. This mixed identity is a result of a combination of the modernization, the population structure and historical factors overviewed in the Introduction. Supposedly, traditional culture left its traces in the way not only urban and rural voters vote, but in the way they define themselves, while Russian modernization influence is seen as a model of political choice when the civilizational choice is in question.

\section{Literature}

Arel, D. (2006). La face cachée de la Révolution Orange: 'Ukraine en négation face à son problème regional. Revue d'études comparatives Est-Ouest, 37, 4, 1-41.

Barrington, L.W. \& Faranda, R. (2009). Reexamining Region, Ethnicity, and Language in Ukraine, Post-Soviet Affairs 25, 3, 232-256.

Bilychenko, S. (2010). Na shcho skhozha elektoral'na karta Ukrainy. [How Does the Electoral Map of Ukraine Looks Like]. "Ukrains'ka Pravda", 24.02.2010. retrived from

Birch, S. (2000). Interpreting the Regional Effect in Ukrainian Politics. Europe-Asia Studies, 52, 6, 1017-1041.

Brubaker, R. (1992). Citizenship and Nationhood in France and Germany. Harvard: Harvard University Press.

Darden, K. (2010). Imperial Footprints: Colonial Legacies, Party machines and Contemporary Voting. Manuscript Paper Prepared for the Midwest Political Science Association Meetings 24.04.2010.

Dashkevych, Y. (1991). Ukraina na mezhi mizh Skhodom I Zakhodom (XII-XIV vv.). [Ukraine at the Border between the East and the West (XII-XIV centuries).] Zapysky naukovoho towarystwa im.Shevchenko: V.CCXXII.

Dnistrianskiy, M. (2000). Ukraina w polityko-geografichnomu wymiri [Ukraine in the political and geographical view.] Lviv: Vydavnychy Tsentr Universytetu I.Franka.

Haller, M. \& Ressler, R. (2006). National and European Identity. A Study of Meaning and Interrelationship. Revue Frances de Sociologie, 47, 817-50.

Hesli, V. L., Reisinger, W. M. \& Miller, A. H. (1998). Political Party Development in Divided Societies: the Case of Ukraine. Electoral Studies, 17, 2, 235-256.

Hutchinson, J. 1987. The Dynamics of Cultural Nationalism. London: Allen and Unwin.

Kasjanov, G. (1999). Teorii natsi ta natsionalizmu [Theories of Nations and Nationalism]. Kyiv: Lybid'.

Khmelko, V. \& Wilson, A. (1998). Regionalism and Ethnic and Linguistic Cleavages in Ukraine'. In T. Kuzio (Ed.) Contemporary Ukraine: Dynamics of Post Soviet Transformation. London: M.E. Sharpe.

Kohn, H. (1967). The Idea of Nationalism: A Study of Its Origin and Background. New York: Collier Books.

Kotkin, S. (1995). Magnetic Mountain: Stalinism As A Civilization. University of California Press.

Krawchenko, B.(1985). Social Change and National Consciousness in Twentieth-Century Ukraine. London: The Macmillan Press Ltd.

Kubicek, P. (2000). Regional Polarization in Ukraine: Public Opinion, Voting and Legislative Behaviour. Europe-Asia Studies, 52, 2, 273-294. 
Lypynsky, V. (1995 (1926)) Ukraina na perelomi [Ukraine at the Threshold]. Collected works, letters, papers and miscellanea. Historical section, 3. Kiev-Philadelphia: East-European Research Institute NAS of Ukraine.

Magosci, P.R. (1996). A Hostory of Ukraine. Toronto: University of Toronto Press.

McNeill, W. H. (2011(1964)). Europe's Steppe Frontier, 1500-1800. University Chicago Press.

Moklak, Ya. (2006). Ukraińskie tradycje parlamentarne, XIX-XXI wiek. [Ukrainian Parlamentarian Ttraditions]. Kraków: Historia Jagellonica.

Motyl, A. \& Krawchenko, B. (1997). Ukraine from Empire to Statehood. In I. Bremmer and R. Taras (Eds.), New States, New Politics. Building the Post-Soviet Nations. Cambridge: Cambridge University Press.

Nichoga, M. (2010). Zitknennia tsyvilizatsiy poseredyni Ukrainy. [The Clash Of Civilization in the Middle of Ukraine]. "Ukrains'ka Pravda", 11.06.2010.

Peisakhin, L. (2012). In History's Shadow: Persistence of Identities and Contemporary Political Behavior. Working papers / Instituto Juan March de Estudios e Investigaciones, Centro de Estudios Avanzados en Ciencias Sociales, 2012/272.

Prysiazhniuk, Yu. (2008). Ukrain'ske selianstwo Naddniprianschyny drugoji polovyny XIX-pochatku XX stolittia. [Ukrainian peasants from the Dnieper Ukraine in the second half XIX - early XX-th century]. Dnipropetrovsk: Dnipropetrovsk National University.

Shabliy, O. I. (1995). Sotsial'no-ekonomicheskaya geografiia Ukrainy. [Social-Economic geography of Ukraine .] Lviv: Svit.

Shulman, S. (2005). National identity and Public Support for Political and economic Reform in Ukraine. Slavic Review, 64,1, 59-87.

Smith, A. (1991). National Identity. Penguin.

Yakovenko, N. (2009). Narysy istorii seredniovichnoi ta ranniomodernoi Ukrainy [Outlines of the medieval and early modern history of Ukraine]. Kiev: Krytyka. 